\title{
The Visegrád Group - A Rising Star Post-Brexit? Changing Distribution of Power in the European Council
}

DOI 10.1515/openps-2017-0001

received January 30, 2017; accepted March 27, 2017.

\begin{abstract}
The portmanteau Brexit describes the withdrawal of the United Kingdom (UK) from the European Union (EU) which will cause a shift of power in the European institutions. The departure of one of the largest EU members will affect the voting power of member countries in the European Council significantly. This Council is the central hub of political decision making in the EU, defining the overall political direction and priorities and setting the policy agenda for the entirety of the EU. Using the Banzhaf power index, we have measured the voting power before and after the Brexit and analyzed the increasing power of the members of the Visegrád Group compared to other European states. We have found that there is growth in the voting power of all Visegrád states, with Poland experiencing the biggest increase. However, the extent by which the Visegrád Group will profit from this statistically growing power depends on the coordination of their voting behavior in the future.
\end{abstract}

Keywords: Visegrád countries, European Council, voting power, coalition building, Brexit

\section{Political constellations in the European Union after Brexit}

On June 23, 2016 the British electorate decided in a respectable turnout of 72.2\%, the United Kingdom's (UK) place in Europe and the World. Hoping to regain their international power and influence by leaving the European Union (EU) and thus reclaim political and economic independence, 51.9\% of voters chose for the UK to leave the EU. This to a large extent unexpected decision has troubled British society, politics, and the economy and has caused division between those who voted for Remain and Leave, particularly along regional borders. While most regions voted to leave, London, Northern Ireland, Scotland, and Gibraltar ${ }^{1}$ opposed this disintegrative objective. This referendum could, theoretically, lead to the break-up of the UK as a result of another Scottish independence referendum aiming on reintegrating this Northern region into the EU. This rather unlikely scenario and the UK's decision to leave the EU have only added to the growing scepticism about Europe's future after the real exit of the UK in presumably several years.

Irrespective of the obvious political, economic, and social issues the EU referendum will provoke in the UK, as well as in Europe as a whole, we have to assume that the EU will continue to exist as the only framework securing European countries' political stability, prosperity and global position despite growing disintegrative forces. But on the other hand there is already conflict brewing about concepts and levels of European integration, which will flare up, and most likely cause a change in the design of the EU.

1 Other local areas voted against Brexit, too. See The Electoral Commission, http://www.electoralcommission.org.uk/findinformation-by-subject/elections-and-referendums/upcoming-elections-and-referendums/eu-referendum/electorate-andcount-information (accessed: July 28, 2016).

*Corresponding author: Ralf Thomas Göllner, Universität Regensburg, E-mail: Ralf.Goellner@politik.uni-r.de 
The UK with the third largest population in the EU was presumed to be a crucial part of the overall equilibrium in Europe when market orientation, free-trade, economic liberalism, and balanced integration were considered in contrast to dirigisme, protectionism, deeper integration and growing EU budgets. The UK is one of the economically most liberal and less regulated countries with the second lowest score for state control (Koske et al. 2016). Together with Ireland, the Netherlands, the Nordics and some Eastern Europeans it is a principal agent for economic liberalization in the European Council, representing about $25 \%$ of votes (Irwin 2015, 14-15). In the past, Germany as a swing voter used to balance and mediate between this liberal and the opposing, more regulatory and state-interventionist bloc, which includes most notably the Mediterranean countries and some Eastern and Western European states. In the near future, different actors or blocs in Europe are seen as possible beneficiaries of UK's exit from the EU because of their hence growing political influence and ability to shape the future of the EU. This could possibly shift the focus away from liberal economic concepts towards regulatory and state-interventionist ones, at the same moment dissolving the latter and establishing another major player on the European scene. It is, however, more likely that the European matrix of interests will become even more diverse and attempt to safeguard the EU's future on a broader basis.

The political constellations after the financial crisis of 2008 are indicators for some new European alliances, overriding the hitherto existing liberal-regulatory antagonism. Following the financial crisis and the Greek debt crisis, which started in 2010, the traditional European microstructure of cooperation has been rearranged and extended. The German-French dynamics have slowed down dramatically, Spain and Italy have fallen even further behind and the UK has refused to play an active political role on the European stage. Voting records in the European Council show that between 2009 and 2015 the UK was on the losing side $12.3 \%$ of the time, the highest percentage for any member state. Germany and Austria, in joint second place, were on the losing side for only 5.4\% of votes (Hix, Hagemann, and Frantescu 2016, 4). The weakening of Germany's traditional political partners has led to intensified relations with new member states, in particular Poland. Contrary to Southern European member states, most Eastern European member states were in line with German austerity policy, emphasizing budgetary discipline and cost-saving reforms just as they had implemented in the transition period. But, this emerging alliance was fragile from the beginning and has been affected by the political course of the PiS government in Poland and later by Germany's attitude and claims during the refugee crisis of 2015/16. Eastern European politicians perceived Germany's demands as invasive and inadequate and the overall situation seemed to weaken the basis for cooperation between Germany and Eastern Europe.

Nevertheless, these incidences brought the Eastern European states closer again, revitalizing the Visegrád Group (V4) especially, which was established in 1991 as a core of cooperation and coordination vis-à-vis Western Europe, but mainly Russia. This formalized cooperation between the Czech Republic, Hungary, Poland, and Slovakia was weakened following the enlargement of the EU and especially by different attitudes and politics towards Russia when the Ukraine crisis broke out in 2014. The voting behavior of these countries in the European Council did not suggest the building of a coalition since variance was very high (Hix, Hagemann, and Frantescu 2016), but the refugee crisis one year later helped to overcome dissent and cooperation intensified once again. This could have an impact on voting behavior in the Council. Post-Brexit the Visegrád countries will lose "an invaluable ally [...] because it shared a 'common perception of European problems', as Poland's foreign minister, Witold Waszczykowski, put it" (Connolly 2016). A joint contribution by the foreign ministers of France and Germany four days after the British referendum confirmed the Visegrád countries' concerns about Europe's future development. Both Western politicians announced a "move further towards political union in Europe" and they emphasized that there is a "need to recognise that member states differ in their levels of ambition [...] when it comes to the project of European integration" (Ayrault and Steinmeier 2016). Irrespective of ruling parties' ideological affiliation, Visegrád countries reject a deeper integration, a two-speed and more regulatory Europe and mandatory quotas for refugees, and following Brexit they will lose their leading EU partner in these critical policy areas. In addition, among the Visegrád countries only Slovakia is part of the Eurozone and "Brexit is likely to enhance the power of the eurozone within the EU" (Oliver 2016, 4). There seems to be at least a Visegrád Group or even an Eastern European idea on Europe's future design and politics that could influence these countries in building of coalitions and voting in the European Council. 
Therefore, it is worth analyzing possible post-Brexit constellations in the European Council on the basis of the changing distribution of power, indicating the emergence of the most probable winning or blocking coalitions. There are different alternatives to measure power, but we have used the (normalized) Banzhaf power index, measuring "the relative ability of each member to affect the outcome of the group's decisions through his vote" (Banzhaf 1966, 1315). This index is used widely to measure voting power, not only in the European Council.

\section{Changes in voting power in the European Council}

The European Council makes decisions using simple majority, qualified majority and unanimous vote, but the most issues are decided by qualified majority voting (QMV). In voting bodies like the European Council votes have different voting powers, because of their differing "ability to affect outcomes by participating in the voting process" (Banzhaf 1966, 1315). QMV in the European Council has always been based on weighted votes and certain quotas. Prior to the Lisbon Treaty the triple majority rule implemented by the Treaty of Nice was used (Felsenthal and Machover 2001; Leech 2001). However, this did not take into account the size of a member state's population and therefore the same voting power was assigned to the four largest EU members Germany, France, United Kingdom and Italy and a majority threshold of 260 votes out of total 352 with an optional condition of $62 \%$ of the total EU population was used. Table 1 shows the populations and voting powers according to the existing decision rules under the Treaty of Lisbon, signed on 13 December 2007, implementing a simplified double majority system and prescribing that as of 1 November 2014 "a qualified majority shall be defined as at least 55\% of the members of the Council representing the participating Member States, comprising at least $65 \%$ of the population of these States. A blocking minority must include at least four Council members, failing which the qualified majority shall be deemed attained" $(2007,18)$. In addition, another threshold of $72 \%$ for special decisions as well as a transitional period from 1 November 2014 to 31 March 2017 has been introduced. As a consequence, the four largest EU member states, especially Germany, have gained significantly more voting power at the expense of medium sized states (Göllner 2016). Thus, decisions depend "explicitly on the size of population of the member-states" and "will be automatically affected by demographic changes" (Felsenthal and Machover 2009, 318-319). Changes in the size of the EU, due to enlargements or exits by member states, do not require the assignment of new voting weights, but will affect voting power through change in population ratios. As the UK is leaving the EU, voting power of the other members is automatically changing due to rising population ratio. We would therefore expect an increase in voting power for all remaining members, but indeed the larger countries such as Germany, France, Italy, Spain and Poland expand their voting power above the average at the expense of the smaller countries. In fact, the biggest winner in voting power postBrexit is Poland, gaining 27.8\% in relative terms, followed by Spain gaining 23.0\%. The Czech Republic gains $4.0 \%$, Hungary $3.6 \%$ and Slovakia $0.7 \%$ voting power. In total, Brexit will increase the voting power of Visegrád Group by $36.1 \%$. Member states with less than roughly 4.4 Million citizens will lose power, with the turning-point currently deviating between Ireland and Croatia. Table 2 illustrates these changes in voting power for the post-Brexit EU. This can be explained by the diminishing pivotal function of smaller states following Brexit, thus reducing the significance of supporting countries to the advantage of the population factor. Furthermore, while in the EU 28 there were 30,401,043 winning coalitions, this will drop to $17,700,989$ after Brexit, increasing the probability of reaching a decision from $11.3 \%$ to $13.2 \%$ (König and Bräuninger 2000), also adding to the influence the Visegrád Group could exert.

Another critical point is the high number of migrants from Visegrád countries working in the UK. According to Eurostat ${ }^{2}$, there were 869,061 Poles, 86,519 Hungarians and 80,771 Slovaks registered in the UK in 2015. Anti-Eastern European and especially anti-Polish sentiments increased dramatically after

2 http://ec.europa.eu/eurostat/web/population-demography-migration-projections/population-data/database, (Code migr_ pop1ctz) (accessed July 28, 2016). 
the Brexit referendum, which was in part a referendum against migration. Assuming the very unlikely case that all migrants from Eastern Europe will be expelled and return home, the rising population of Visegrád countries has virtually no effect on these countries' voting power. Poland's voting power would rise to $6.5998 \%(+0.1104 \%)$, although the number of Polish migrants approximately equals the population of Cyprus. Hungary's power would rise to $2.8553 \%$ (+0.0049\%) and Slovakia's to $2.3294 \%(+0.0063 \%)$. However, since voting power strongly depend on member states' population size, it's worth looking into anticipated changes for the Visegrád countries. Kóczy (2016) has calculated the Shapley-Shubik power index until 2080 on the basis of Eurostat population projections. As a result the predicted decline in population of Poland, Slovakia and Hungary as opposed to the predicted population growth in the Czech Republic over the next 60 years will have a significant impact on the Visegrád countries' voting power. He predicts a remarkable decline of voting power for the three countries due to population decrease.

Table 1: Population, ${ }^{3}$ weighted votes and Banzhaf power index ${ }^{4}$ - Treaty of Lisbon.

\begin{tabular}{|c|c|c|c|c|}
\hline & Population & Population in \% & Weighted votes & $\begin{array}{l}\text { Banzhaf-power index } \\
\text { (triple majority system) in \% }\end{array}$ \\
\hline Germany & $82,162,000$ & 16.1 & 29 & 7.7828 \\
\hline France & $66,661,621$ & 13.1 & 29 & 7.7828 \\
\hline United Kingdom & $65,341,183$ & 12.8 & 29 & 7.7827 \\
\hline Italy & $60,665,551$ & 11.9 & 29 & 7.7827 \\
\hline Spain & $46,438,422$ & 9.1 & 27 & 7.4199 \\
\hline Poland & $37,967,209$ & 7.4 & 27 & 7.4198 \\
\hline Romania & $19,759,968$ & 3.9 & 14 & 4.2591 \\
\hline Netherlands & $16,979,120$ & 3.3 & 13 & 3.9740 \\
\hline Belgium & $11,289,853$ & 2.2 & 12 & 3.6843 \\
\hline Greece & $10,793,526$ & 2.1 & 12 & 3.6843 \\
\hline Czech Republic & $10,553,843$ & 2.1 & 12 & 3.6843 \\
\hline Portugal & $10,341,330$ & 2.0 & 12 & 3.6843 \\
\hline Hungary & $9,830,485$ & 1.9 & 12 & 3.6843 \\
\hline Sweden & $9,851,017$ & 1.9 & 10 & 3.0924 \\
\hline Austria & $8,700,471$ & 1.7 & 10 & 3.0924 \\
\hline Bulgaria & $7,153,784$ & 1.4 & 10 & 3.0924 \\
\hline Denmark & $5,707,251$ & 1.1 & 7 & 2.1809 \\
\hline Finland & $5,487,308$ & 1.1 & 7 & 2.1809 \\
\hline Slovakia & $5,426,252$ & 1.1 & 7 & 2.1809 \\
\hline Ireland & $4,658,530$ & 0.9 & 7 & 2.1809 \\
\hline Croatia & $4,190,669$ & 0.8 & 7 & 2.1809 \\
\hline Lithuania & $2,888,558$ & 0.6 & 7 & 2.1809 \\
\hline Slovenia & $2,064,188$ & 0.4 & 4 & 1.2502 \\
\hline Latvia & $1,968,957$ & 0.4 & 4 & 1.2502 \\
\hline Estonia & $1,315,944$ & 0.3 & 4 & 1.2502 \\
\hline Cyprus & 848,319 & 0.2 & 4 & 1.2502 \\
\hline
\end{tabular}

3 Data on population in the EU according Eurostat, F2: Population, Forecast population on January 1, 2016. http://ec.europa. eu/eurostat/web/population-demography-migration-projections/population-data/main-tables, Code: tps0001 (accessed July 26, 2016).

4 The Banzhaf power index was calculated with the open access program "Indices of Power IOP 2.0" by Thomas Bräuninger and Thomas König, http://www.tbraeuninger.de/download/ (accessed July 26, 2016). 
Table 1: Population, ${ }^{3}$ weighted votes and Banzhaf power index ${ }^{4}$ - Treaty of Lisbon.

\begin{tabular}{lrrll}
\hline & Population & Population in \% & Weighted votes & $\begin{array}{l}\text { Banzhaf-power index } \\
\text { (triple majority system) in \% }\end{array}$ \\
\hline Luxembourg & 576,249 & 0.1 & 4 & 1.2502 \\
Malta & 434,403 & 0.1 & 3 & 0.9422 \\
EU 28 & $510,056,011$ & 100 & 352 & 100 \\
EU 27 & $444,714,828$ & & & \\
\hline
\end{tabular}

\section{Summary and conclusions}

The Central Eastern European Countries dispose of the Visegrád Group as a potentially powerful actor on the European scene. Until now, they didn't make use of it in their voting behavior, thus missing chances to express common interests with one voice in the European Council. In contrast, a Mediterranean bloc, made up by France, Spain, and Italy and complemented by Romania (Hix, Hagemann, and Frantescu 2016), is already enforcing shared interests and will gain plenty of voting power after Brexit (+64.6\%). If the Visegrád Group could align their interests and strategically coordinate their voting behavior in the Council (Napel and Wildgrén 2011), they could become a pivotal player on the European scene. The Visegrád cooperation is an existing institution but an insufficiently utilized framework for the coordination of policies and voting behaviors. However, a rise in voting power could negate some of the disadvantages caused by Brexit if this power is translated into decision making and the formation of coalitions.

Table 2: Voting powers in the European Council before and after Brexit.

\begin{tabular}{|c|c|c|c|c|c|c|}
\hline & \multicolumn{2}{|c|}{ EU 28 before Brexit } & \multicolumn{2}{|c|}{ EU 27 after Brexit } & \multirow[b]{2}{*}{$\begin{array}{l}\text { Changes of } \\
\text { voting power } \\
\text { in } \%\end{array}$} & \multirow[b]{2}{*}{$\begin{array}{l}\text { Relative changes } \\
\text { of voting power } \\
\text { in } \%\end{array}$} \\
\hline & $\begin{array}{l}\text { Population } \\
\text { in } \%\end{array}$ & $\begin{array}{l}\text { Banzhaf-power index } \\
\text { (double majority systems) }\end{array}$ & $\begin{array}{l}\text { Population } \\
\text { in } \%\end{array}$ & $\begin{array}{l}\text { Banzhaf- } \\
\text { power index }\end{array}$ & & \\
\hline Germany & 16.1 & 10.2760 & 18.5 & 12.0099 & +1.7339 & +16.9 \\
\hline France & 13.1 & 8.4444 & 15.0 & 9.9769 & +1.5325 & +18.1 \\
\hline United Kingdom & 12.8 & 8.2953 & & & & \\
\hline Italy & 11.9 & 7.8046 & 13.6 & 9.1136 & +1.309 & +16.8 \\
\hline Spain & 9.1 & 6.1914 & 10.4 & 7.6161 & +1.4247 & +23.0 \\
\hline Poland & 7.4 & 5.0770 & 8.5 & 6.4894 & +1.4124 & +27.8 \\
\hline Romania & 3.9 & 3.7577 & 4.4 & 4.0094 & +0.2517 & +6.7 \\
\hline Netherlands & 3.3 & 3.4709 & 3.8 & 3.6917 & +0.2208 & +6.4 \\
\hline Belgium & 2.2 & 2.8969 & 2.5 & 3.0241 & +0.1272 & +4.4 \\
\hline Greece & 2.1 & 2.8471 & 2.4 & 2.9650 & +0.1179 & +4.1 \\
\hline Czech Republic & 2.1 & 2.8229 & 2.4 & 2.9366 & +0.1137 & +4.0 \\
\hline Portugal & 2.0 & 2.8015 & 2.3 & 2.9113 & +0.1098 & +3.9 \\
\hline Sweden & 1.9 & 2.7522 & 2.2 & 2.8529 & +0.1007 & +3.7 \\
\hline Hungary & 1.9 & 2.7502 & 2.2 & 2.8504 & +0.1002 & +3.6 \\
\hline Austria & 1.7 & 2.6366 & 1.9 & 2.7154 & +0.0788 & +3.0 \\
\hline Bulgaria & 1.4 & 2.4811 & 1.6 & 2.5303 & +0.0492 & +2.0 \\
\hline Denmark & 1.1 & 2.3353 & 1.3 & 2.3569 & +0.0216 & +0.9 \\
\hline Finland & 1.1 & 2.3131 & 1.2 & 2.3305 & +0.0174 & +0.7 \\
\hline Slovakia & 1.1 & 2.3069 & 1.2 & 2.3231 & +0.0162 & +0.7 \\
\hline
\end{tabular}


Table 2: Voting powers in the European Council before and after Brexit.

\begin{tabular}{|c|c|c|c|c|c|c|}
\hline & \multicolumn{2}{|c|}{ EU 28 before Brexit } & \multicolumn{2}{|c|}{ EU 27 after Brexit } & \multirow[b]{2}{*}{$\begin{array}{l}\text { Changes of } \\
\text { voting power } \\
\text { in } \%\end{array}$} & \multirow[b]{2}{*}{$\begin{array}{l}\text { Relative changes } \\
\text { of voting power } \\
\text { in } \%\end{array}$} \\
\hline & $\begin{array}{l}\text { Population } \\
\text { in } \%\end{array}$ & $\begin{array}{l}\text { Banzhaf-power index } \\
\text { (double majority systems) }\end{array}$ & $\begin{array}{l}\text { Population } \\
\text { in } \%\end{array}$ & $\begin{array}{l}\text { Banzhaf- } \\
\text { power index }\end{array}$ & & \\
\hline Ireland & 0.9 & 2.2294 & 1.0 & 2.2308 & +0.0014 & +0.1 \\
\hline Croatia & 0.8 & 2.1822 & 0.9 & 2.1744 & -0.0078 & -0.4 \\
\hline Lithuania & 0.6 & 2.0508 & 0.7 & 2.0172 & -0.0336 & -1.6 \\
\hline Slovenia & 0.4 & 1.9671 & 0.5 & 1.9169 & -0.0502 & -2.5 \\
\hline Latvia & 0.4 & 1.9575 & 0.4 & 1.9055 & -0.052 & -2.7 \\
\hline Estonia & 0.3 & 1.8910 & 0.3 & 1.8264 & -0.0646 & -3.4 \\
\hline Cyprus & 0.2 & 1.8436 & 0.2 & 1.7696 & -0.074 & -4.0 \\
\hline Luxembourg & 0.1 & 1.8159 & 0.1 & 1.7365 & -0.0794 & -4.4 \\
\hline Malta & 0.1 & 1.8014 & 0.1 & 1.7192 & -0.0822 & -4.6 \\
\hline EU 27 & 87.2 & 100.0 & 100.0 & 100.0 & +8.2953 & 100.0 \\
\hline Visegrád Group & 12.5 & 12.959 & 14.3 & 14.5995 & +1.6425 & +36.1 \\
\hline
\end{tabular}

\section{References}

[1] Ayrault, Jean-Marc, and Frank-Walter Steinmeier: “A strong Europe in a world of uncertainties.” https://www. auswaertiges-amt.de/EN/Europa/Aktuell/160624-BM-AM-FRA_ST.html (accessed July 26, 2016).

[2] Banzhaf, John F. III. 1965. “Weighted Voting Doesn’t Work”: A Mathematical Analysis.” Rutgers Law Review 19: 317-43.

[3] Banzhaf, John F. III. 1966. "Multi-Member Electoral Districts. Do They Violate the "One Man, One Vote" Principle." The Yale Law Journal 75 (8): 1309-1338.

[4] Connolly, Kate. 2016. "Eastern bloc countries make demands for less centralised Europe”. The Guardian, July 4, 2016. https://www.theguardian.com/world/2016/jul/04/eastern-bloc-countries-demand-less-centralised-europe (accessed July 26, 2016).

[5] Felsenthal, Dan S., and Moshé Machover. 2001: "The Treaty of Nice and qualified majority voting." Social Choice and Welfare 18: 431-464.

[6] Felsenthal, Dan S., and Moshé Machover. 2009: "The QM Rule in the Nice and Lisbon Treaties: Future Projections." Homo Oeconomicus 26 (3/4): 318-319.

[7] Göllner, Ralf Thomas. 2016. "The Political and Economic Effects of the Eastward Expansion of the European Union for Germany" In Cooperation in Asia and Disintegration in Europe? Proceedings of a German-Korean Academic Dialog, ed. Harald Bergbauer and Yeonho Lee. Baden-Baden: Nomos, 99-134.

[8] Hix, Simon, Sara Hagemann, and Doru Frantescu. 2016. "Would Brexit Matter? The UK's voting records in the Council and the European Parliament.” VoteWatch Europe, Brussels. http://eprints.lse.ac.uk/66261/ (accessed: July 27, 2016).

[9] Irwin, Gregor. 2015. "BREXIT: the impact on the UK and the EU”. London: Global Counsel https://www.global-counsel. co.uk/sites/default/files/special-reports/downloads/Global Counsel_Impact_of_Brexit.pdf (accessed: July 28, 2016).

[10] Kóczy, László Á. 2016. “How Brexit affects European Union power distribution.” Hungarian Academy of Sciences, Discussion papers MT-DP - 2016/11.

[11] König, Thomas, and Thomas Bräuniger. 2000. Governing the Enlarged European Union: Accession Scenarios and Institutional Reform." Central European Political Science Review 1 (1): 42-62.

[12] Koske, Isabell, Isabelle Wanner, Rosamaria Bitetti, and Omar Barbiero. 2015. “The 2013 update of the OECD's database on product market regulation: Policy insights for OECD and non-OECD countries”, OECD Economics Department Working Papers 1200. http://dx.doi.org/10.1787/5js3f5d3n2vl-en (accessed July 26, 2016).

[13] Leech, Dennis. 2001. "Designing the voting system for the Council of the European Union." Public Choice 113: 437-464.

[14] Napel, Stefan, and Mika Wildgrén. 2011. "Strategic versus non-strategic voting power in the EU Council of Ministers: the consultation procedure." Social Choice and Welfare 37: 511-541.

[15] Oliver, Tim. 2016. “European and international views of Brexit.” Journal of European Public Policy, DOI: 10.1080/13501763.2016.1174534: 1-8.

[16] Treaty of Lisbon amending the Treaty on European Union and the Treaty establishing the European Community, signed at Lisbon, 13 December 2007." Official Journal of the European Union 50(C306): 1-229. 